\title{
Fault analysis to Determine Deformation History of Kubang Pasu Formation at South of UniMAP Stadium Hill, Ulu Pauh, Perlis, Malaysia
}

\author{
Adi Suryadi ${ }^{1}$ * \\ ${ }^{1}$ Geological Engineering Program, Faculty of Engineering, Islamic University of Riau \\ Pekanbaru, Riau
}

*Corresponding Author's email: adisuryadi@eng.uir.ac.id

Tel.: +6282283896947

Received: Oct 1, 2016. Revised : 15 Nov 2016, Accepted: Nov 20, 2016, Published: 1 Dec 2016

DOI: $10.24273 /$ jgeet.2016.11.1

Abstract

The Kubang Pasu Formation at South of UniMap Stadium Hill has suffered deformation that produced fault with various types and orientations. First deformation (ST1) is southeast - northwest were resulted normal, reverse, dextral and sinistral fault. At station 32 , Reverse fault $\left(\mathrm{N} 94^{\circ} \mathrm{E} / 48^{\circ}\right)$ from ST1 was cut by reverse fault $\left(\mathrm{N} 48^{\circ} \mathrm{E} / 40^{\circ}\right)$ result of second deformation (ST2). Another cross cutting fault found at station 108, third deformation (ST3) with stress direction from northeast southwest that produced reverse fault with strike direction $\mathrm{N} 134^{\circ} \mathrm{E}$ and $68^{\circ}$ of dip angle was cutting the reverse fault $\left(\mathrm{N} 87^{\circ} \mathrm{E} / 66^{\circ}\right)$ from second deformation. The youngest deformation (ST4) has stress from east - west. At station 110 , normal fault $\left(\mathrm{N} 90^{\circ} \mathrm{E} / 30^{\circ}\right)$ is representing the youngest deformation was cutting the reverse fault (N154 $\mathrm{E} / 52^{\circ}$ ) from third deformation.

Keywords: Deformation, reverse fault, normal fault, dextral fault, sinistral fault, cross cutting.

\section{Introduction}

The study area is located at Bukit Stadium of UniMAP's sport complex, Ulu pauh, Perlis. The area is bounded by latitude $06^{\circ} 28.246^{\prime} \mathrm{N}$ to $06^{\circ} 28.273^{\prime}$ $\mathrm{N}$ and longitude $100^{\circ} 20.923^{\prime} \mathrm{E}$ to $100^{\circ} 21.087^{\prime} \mathrm{E}$ (Figure 1). The outcrop is hill-cut at south of Bukit Stadium with extensive approximately $320 \mathrm{~m}^{2}$. This area was mapped as Kubang Pasu Formation that consist of clastic sedimentary rock (Gobbet, 1973 and Jones, 1981). History of deformation can be determined by observation of tectonic structure. Study about tectonic structure was carried by Zaiton Harun et al. (1999), Gobbet (1973), and Abdul Hadi et al. (1999) at Kubang Pasu Formation. Relationship between structures can be used to determine the relative age of deformation. Cross cutting law is one of many methods to determine the relative age.

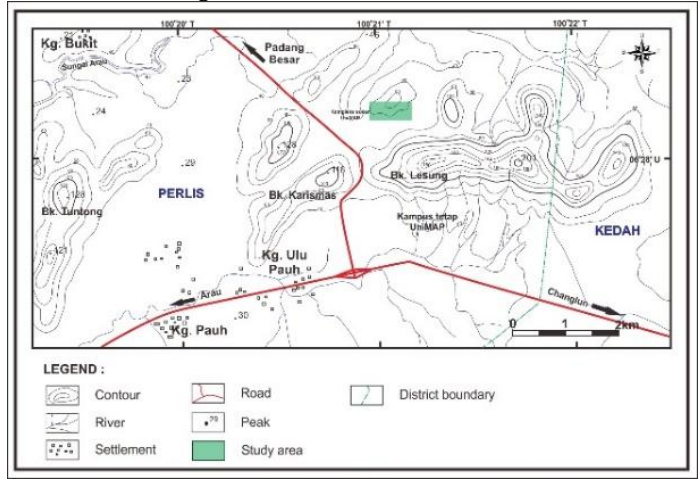

Fig 1. Map of the study area

\section{General Geology and Stratigraphy}

Based on geological map of Peninsular Malaysia show that study area is located at Kubang Pasu Formation. The Kubang Pasu Formation is exposed well at north and center of Perlis and extended to north of Kedah (Basir Jasin et al., 2003). Kubang Pasu and Singa Formation at north of Peninsular Malaysia is same age, the typical characteristic of Kubang Pasu is consist of thick quartz sandstone and interbedded with mudstone (Gobbet, 1973). Thickness of Kubang Pasu Formation is more than $1500 \mathrm{~m}$ that consist of sandstone and mudstone (Foo, 1983). At Bukit Temiang, there are passage beds from clastic rock of Kubang Pasu Formation become limestone of Chuping Formation. Hassan and Lee (2002) said, sometimes there are pebble and cobble at mudstone and shale layers. The age of Kubang Pasu Formation is determined by fossil that found. Trilobite Cyrtosymbole (Waribole) was found at red and grey shale at Gunung Hutan Aji together with bellerophontide, pelecypode, bacutalitide, brakiopode and crinoid stem. All those fossil represent at Late Devonian till Early Carbon (Kobayashi and Hamada, 1973).

Complete sequence of Kubang Pasu Formation exposed at ex-quarry Ladang Cheong Chong Kaw, south of Kampong Panchor and at Kampong Belukar. Bottom part of this formation consist of dark mudstone and dark grey of chert. These layer overlay by interbedded of thin sandstone and thick mudstone. Interbedded of sand stone and mudstone with same thickness is the upper part of Kubang 
Pasu Formation (Zaiton Harun and Basir Jasin, 1999). At Kaki Bukit and Gunung Hutan Aji, lower Paleozoic unit (Setul Formation) and upper Paleozoic unit (Kubang Pasu Formation) is exposed adjacent. There is no clear evidence that show unconformity between Paleozoic unit and Devonian unit.

Lithostratigraphy of study area are divided into the facies association, they are interbedded of sandstone which is the bottommost sequence, followed by fossiliferous thick mudstone and massive sandstone at the uppermost of the sequence.

\section{Structure of Study Area}

North part of Peninsular Malaysia is associated with Bok Bak mega fault. Bok Bak fault at Bukit Jabi

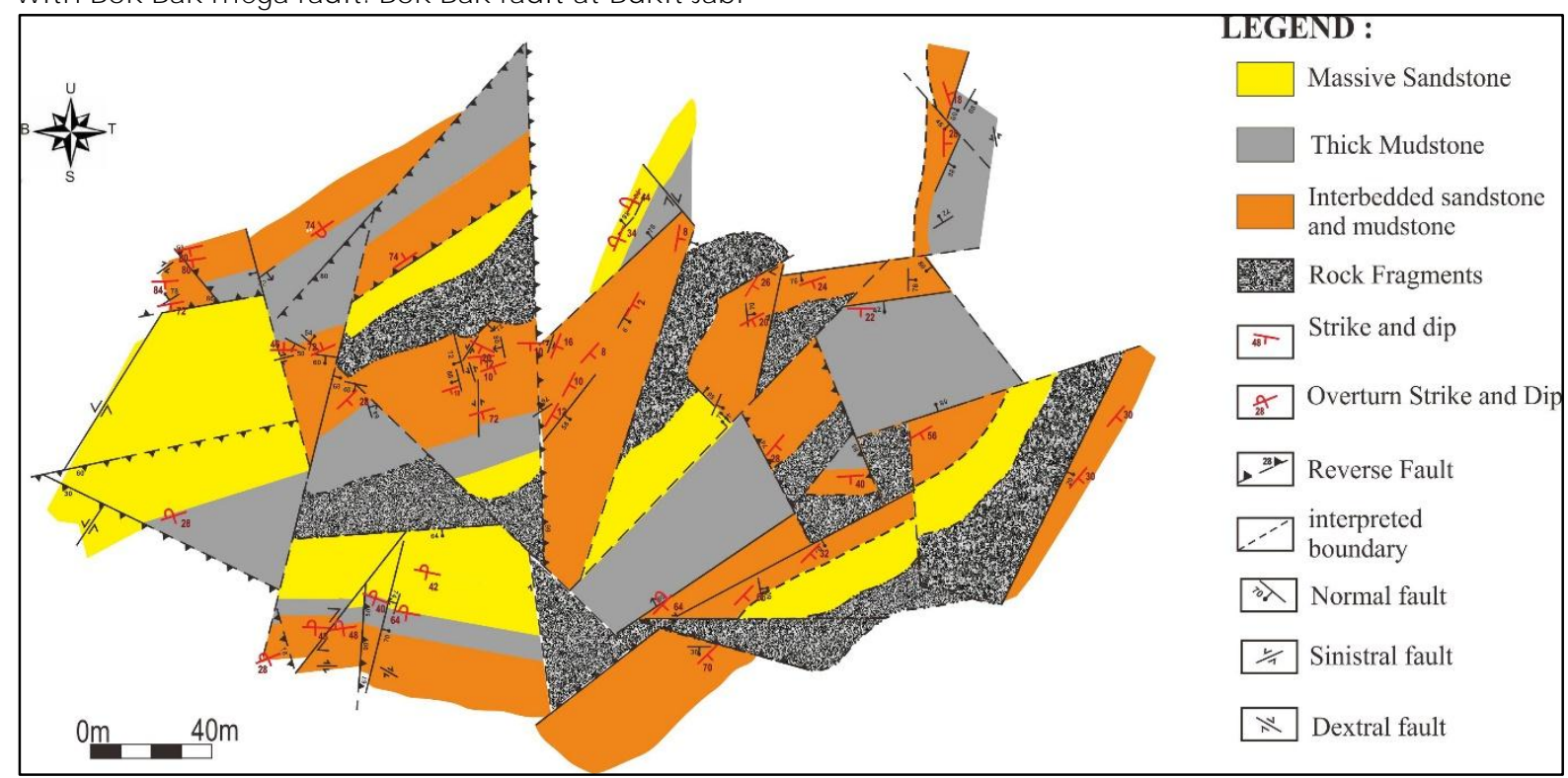

Fig 2. Geological structure map of study area
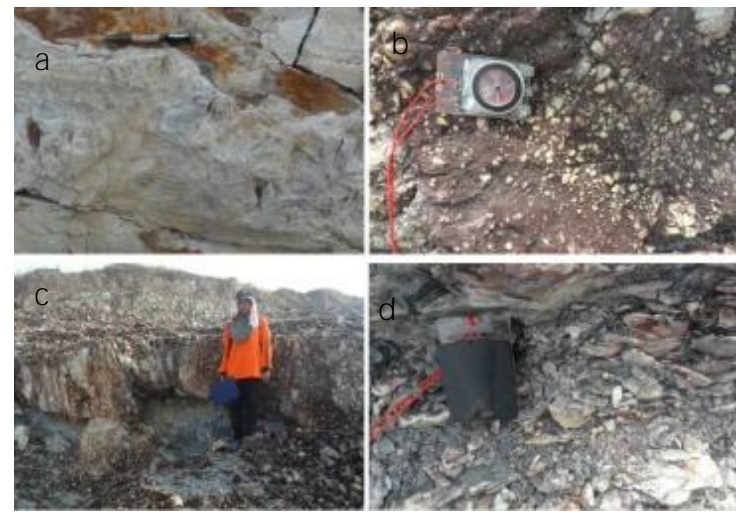

Fig 3. Indication of fault; a. slickenside; b. fault breccia; c. displacement; $d$. mylonite was discussed by Zaiton Harun and Basir Jasin (1999), Mahang formation overlay the Kubang Pasu Formation that younger than it. The boundary between those formations is a milonite zone result of thrust fault caused by Bok Bak fault.

Structure geology of study area is show at figure 2. The bedding in this area has two dominants direction that are east - west and northeast southwest. The dip ranging from $10^{\circ}-80^{\circ}$ toward south and southeast. Furthermore, the dominant structure in the study area is fault. The fault identified in the field are reverse fault, normal fault, sninstral fault and dextral fault. The fault can be identified by presence of mylonite, fault breccias, slickenside, and displacement figure 3.

\subsection{Reverse Fault}

34 strike and dip data of reverse fault was taken from the field. All the data plotted to sterionet to get the major reverse fault and the result shown that there are 4 major reverse faults named as Ss1, Ss2, Ss3 and Ss4 (figure 4). All those faults interpreted as pure reverse fault. Besides that, also there is reverse sinistral fault with pitch toward $N 76^{\circ} \mathrm{E}$ named as SsG. Result of reverse fault analysis represent at Table 1. The result show that there are 4 main stress (compressional stress) which are east-west ( $\mathrm{Ssl}$ and Ss4), southeast-northwest (Ss2), north-south (Ss3) and northeast-southwest (SsG). 


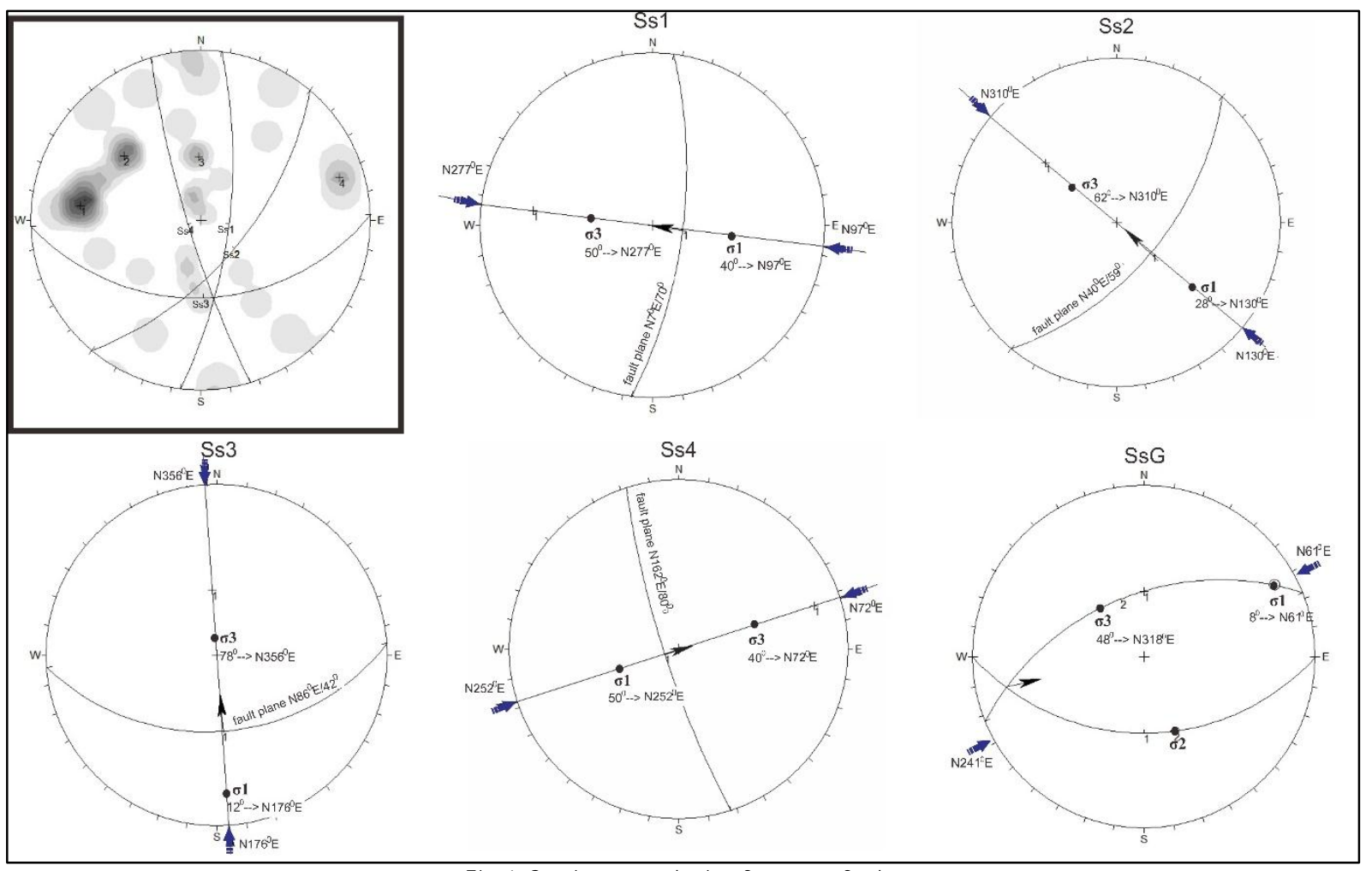

Fig 4. Sterionet analysis of reverse fault

Table 1. Stress analysis result of reverse fault

\begin{tabular}{ccccc}
\hline $\begin{array}{c}\text { Fault } \\
\text { plane }\end{array}$ & Strike and dip & $\begin{array}{c}\text { Pitch } \\
\text { direction }\end{array}$ & Compressional stress $\sigma 1$ & Stress direction \\
\hline Ss1 & $N 7^{\circ} E / 70^{\circ}$ & - & $N 97^{\circ} \mathrm{E}-\mathrm{N} 277^{\circ} \mathrm{E}$ & East-West \\
Ss2 & $\mathrm{N} 40^{\circ} \mathrm{E} / 59^{\circ}$ & - & $\mathrm{N} 130^{\circ} \mathrm{E}-\mathrm{N} 310^{\circ} \mathrm{E}$ & Southeast-northwest \\
Ss3 & $\mathrm{N} 86^{\circ} \mathrm{E} / 42^{\circ}$ & - & $N 176^{\circ} \mathrm{E}-\mathrm{N} 356^{\circ} \mathrm{E}$ & North-South \\
Ss4 & $\mathrm{N} 162^{\circ} \mathrm{E} / 80^{\circ}$ & - & $N 252^{\circ} \mathrm{E}-\mathrm{N} 72^{\circ} \mathrm{E}$ & East-West \\
SsG & $\mathrm{N} 90^{\circ} \mathrm{E} / 42^{\circ}$ & $\mathrm{N} 76^{\circ} \mathrm{E}$ & $\mathrm{N} 318^{\circ} \mathrm{E}-\mathrm{N} 138^{\circ} \mathrm{E}$ & Northeast-southwest \\
\hline
\end{tabular}

\subsection{Normal Fault}

From 47 strike and dip data of normal fault was taken 4 major normal fault labeled as Sn1, Sn2, Sn3 and Sn4 (figure 5). Aside from all those pure normal fault, there are 2 another normal faults found at field. They are normal dextral fault with pitch toward $\mathrm{N} 240^{\circ} \mathrm{E}(\mathrm{SnG} 1)$ and normal sinistral fault with pitch toward $\mathrm{N}^{\circ} \mathrm{E}(\mathrm{SnG} 2)$. The result of normal fault analysis (Table 2) show that there are 4 extensional stress which are north-south (Sn1), northwest-southeast $(\mathrm{Sn} 2)$, east-west $(\mathrm{Sn} 3)$ and northeast-southwest (Sn4, SnG1 and SnG2).

\subsection{Dextral Fault}

5 major dextral fault plane was got from plotting 18 strike and dip data from field observation. 5 major dextral fault interpreted as pure dextral fault that labeled as Ska1, Ska2, Ska3, Ska4 and Ska5 (figure 6). Data and results of analysis of dextral fault show at Table 3 . There are 3 main stress (compressional stress) that generate all of those faults at study area, they are stress from northeastsouthwest (Ska1), north-south (Ska2 and Ska3) and northwest-southeast (Ska4 and Ska5). 


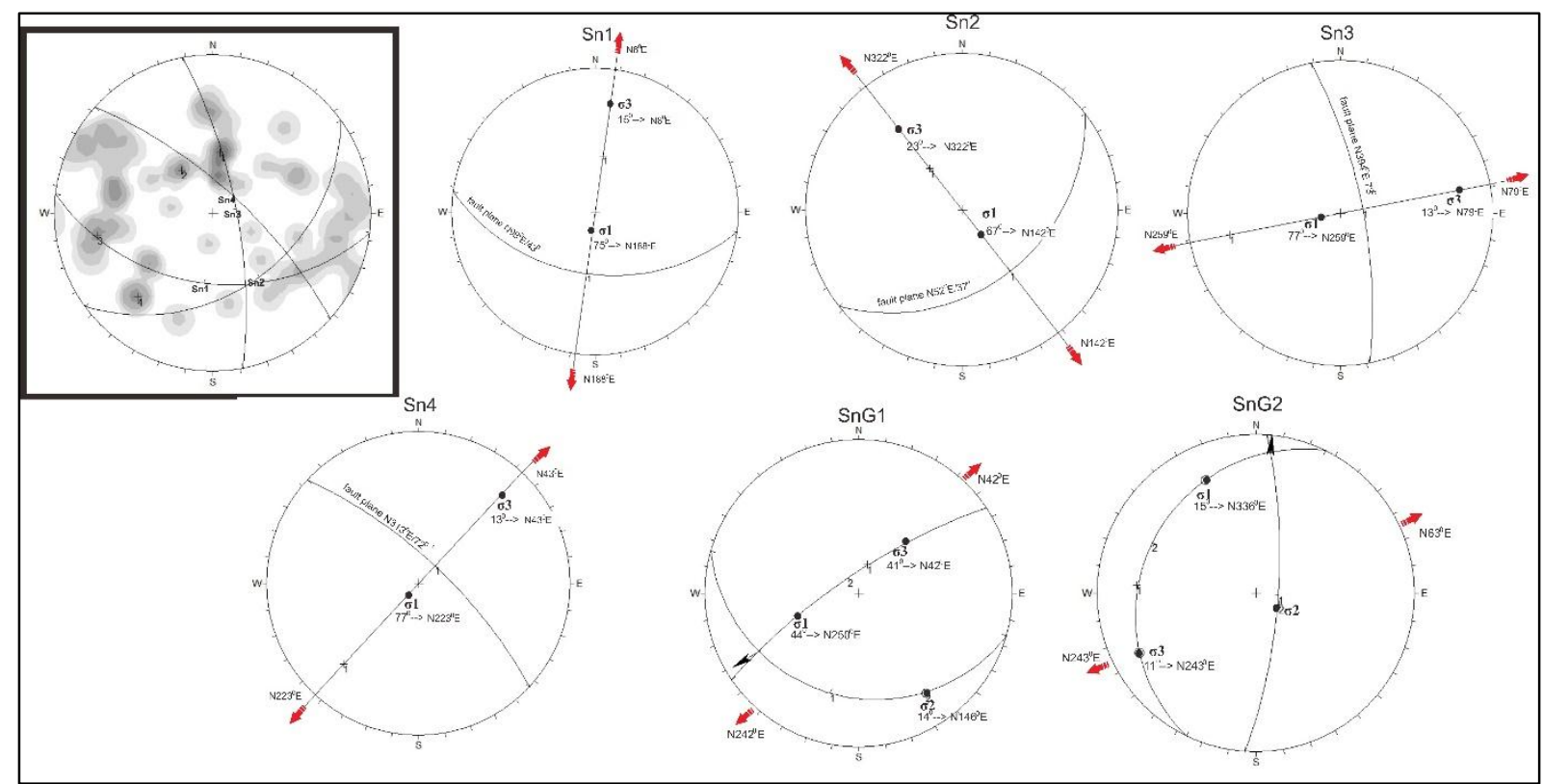

Fig. 5 Sterionet analysis of normal fault

Table 2. Stress analysis result of normal fault

\begin{tabular}{ccccc}
\hline $\begin{array}{c}\text { Fault } \\
\text { plane }\end{array}$ & Strike and dip & $\begin{array}{c}\text { Pitch } \\
\text { direction }\end{array}$ & Extensional stress $\sigma 3$ & Stress direction \\
\hline Sn1 & $\mathrm{N} 98^{\circ} \mathrm{E} / 43^{\circ}$ & - & $\mathrm{N} 8^{\circ} \mathrm{E}-\mathrm{N} 188^{\circ} \mathrm{E}$ & $\begin{array}{c}\text { North-south } \\
\text { Sn2 }\end{array}$ \\
$\mathrm{N} 52^{\circ} \mathrm{E} / 37^{\circ}$ & - & $\mathrm{N} 142^{\circ} \mathrm{E}-\mathrm{N} 322^{\circ} \mathrm{E}$ & Northwest-southeast \\
Sn3 & $\mathrm{N} 349^{\circ} \mathrm{E} / 73^{\circ}$ & - & $\mathrm{N} 79^{\circ} \mathrm{E}-\mathrm{N} 259^{\circ} \mathrm{E}$ & East-west \\
Sn4 & $\mathrm{N} 313^{\circ} \mathrm{E} / 72^{\circ}$ & - & $\mathrm{N} 43^{\circ} \mathrm{E}-\mathrm{N} 223^{\circ} \mathrm{E}$ & Northeast-southwest \\
SnG1 & $\mathrm{N} 106^{\circ} \mathrm{E} / 22^{\circ}$ & $\mathrm{N} 240^{\circ} \mathrm{E}$ & $\mathrm{N} 42^{\circ} \mathrm{E}-\mathrm{N} 222^{\circ} \mathrm{E}$ & Northeast-southwest \\
SnG2 & $\mathrm{N} 4^{\circ} \mathrm{E} / 74^{\circ}$ & $\mathrm{N} 6^{\circ} \mathrm{E}$ & $\mathrm{N} 243^{\circ} \mathrm{E}-\mathrm{N} 63^{\circ} \mathrm{E}$ & Northeast-southwest \\
\hline
\end{tabular}
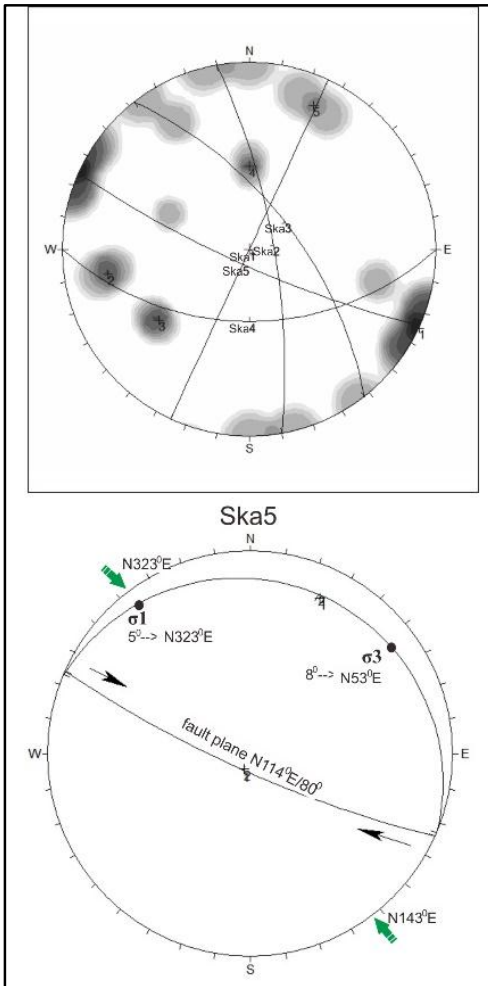
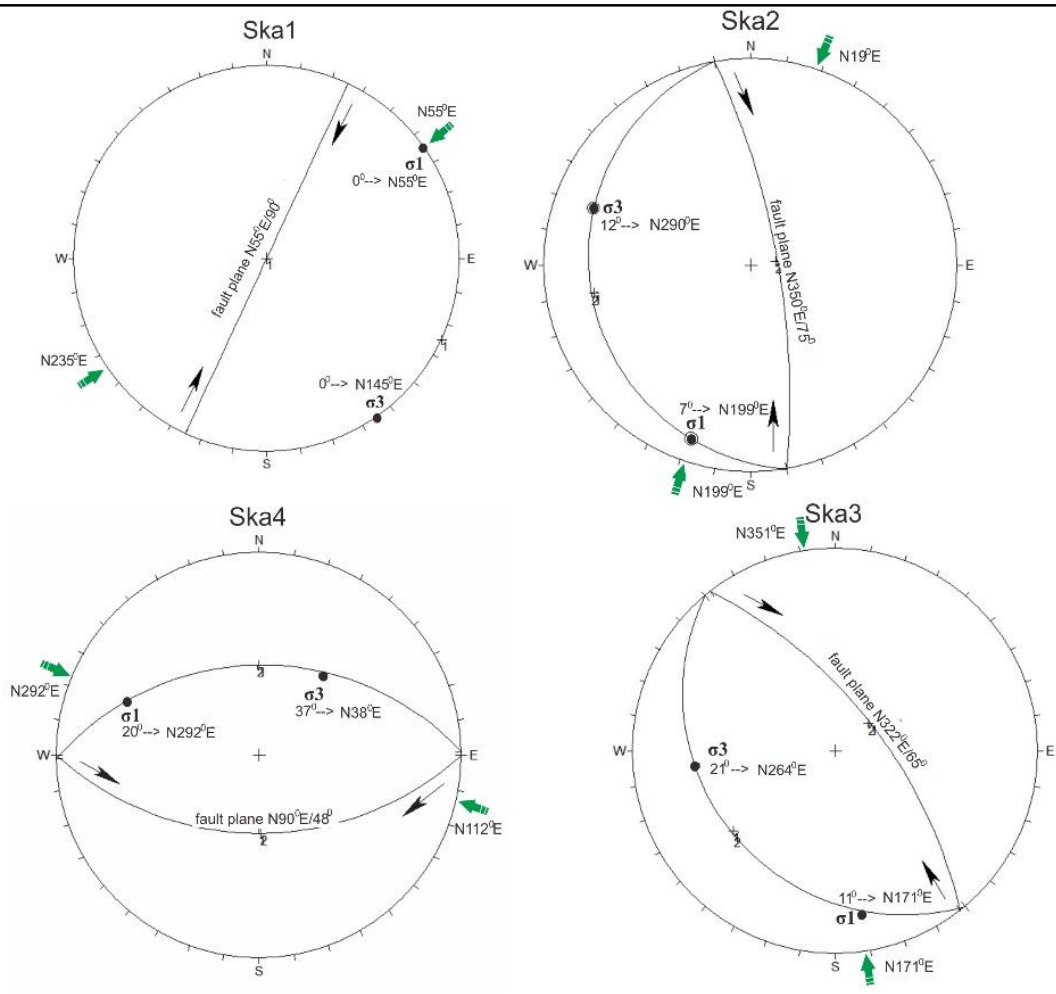

Fig 6. Stress analysis result of dextral fault 
Table 3. Stress analysis result of dextral fault

\begin{tabular}{cccc}
\hline Fault plane & Strike and dip & Compressional stress $\sigma 1$ & Stress direction \\
\hline Ska1 & $\mathrm{N} 205^{\circ} \mathrm{E} / 90^{\circ}$ & $\mathrm{N} 55^{\circ} \mathrm{E}-\mathrm{N} 235^{\circ} \mathrm{E}$ & Northeast-southwest \\
Ska2 & $\mathrm{N} 350^{\circ} \mathrm{E} / 70^{\circ}$ & $\mathrm{N} 199^{\circ} \mathrm{E}-\mathrm{N} 19^{\circ} \mathrm{E}$ & North-south \\
Ska3 & $\mathrm{N} 322^{\circ} \mathrm{E} / 65^{\circ}$ & $\mathrm{N} 177^{\circ} \mathrm{E}-\mathrm{N} 357^{\circ} \mathrm{E}$ & North-south \\
Ska4 & $\mathrm{N} 90^{\circ} \mathrm{E} / 48^{\circ}$ & $\mathrm{N} 292^{\circ} \mathrm{E}-\mathrm{N} 112^{\circ} \mathrm{E}$ & Northwest-southeast \\
Ska5 & $\mathrm{N} 114^{\circ} \mathrm{E} / 80^{\circ}$ & $\mathrm{N} 325^{\circ} \mathrm{E}-\mathrm{N} 145^{\circ} \mathrm{E}$ & Northwest-southeast \\
\hline
\end{tabular}

\subsection{Sinistral Fault}

From 12 strike and dip data of sinistral fault was taken 3 major sinistral fault labeled as Ski1, Ski2 and Ski3 (figure 7). All of them interpreted as pure sinistral fault. Based on analysis of sinistral fault (Table 4), there are 3 main stresses which are north-south (Ski1), northwest-southeast (Ski2) and northeast-southwest (Ski3).

Table 4. Stress analysis result of sinistral fault

\begin{tabular}{cccc}
\hline $\begin{array}{c}\text { Fault } \\
\text { plane }\end{array}$ & $\begin{array}{c}\text { Strike and } \\
\text { dip }\end{array}$ & $\begin{array}{c}\text { Compressional } \\
\text { stress } \sigma 1\end{array}$ & $\begin{array}{c}\text { Stress } \\
\text { direction }\end{array}$ \\
\hline Ski1 & $N 27^{\circ} \mathrm{E} / 90^{\circ}$ & $\mathrm{N} 358^{\circ} \mathrm{E}-\mathrm{N} 178^{\circ} \mathrm{E}$ & $\begin{array}{c}\text { North-south } \\
\text { Ski2 }\end{array}$ \\
$\mathrm{N} 177^{\circ} \mathrm{E} / 88^{\circ}$ & $\mathrm{N} 150^{\circ} \mathrm{E}-\mathrm{N} 330^{\circ} \mathrm{E}$ & $\begin{array}{c}\text { Southeast- } \\
\text { northwest }\end{array}$ \\
Ski3 & $\mathrm{N} 81^{\circ} \mathrm{E} / 61^{\circ}$ & $\mathrm{N} 55^{\circ} \mathrm{E}-\mathrm{N} 235^{\circ} \mathrm{E}$ & $\begin{array}{c}\text { Northeast- } \\
\text { southwest }\end{array}$ \\
\hline
\end{tabular}

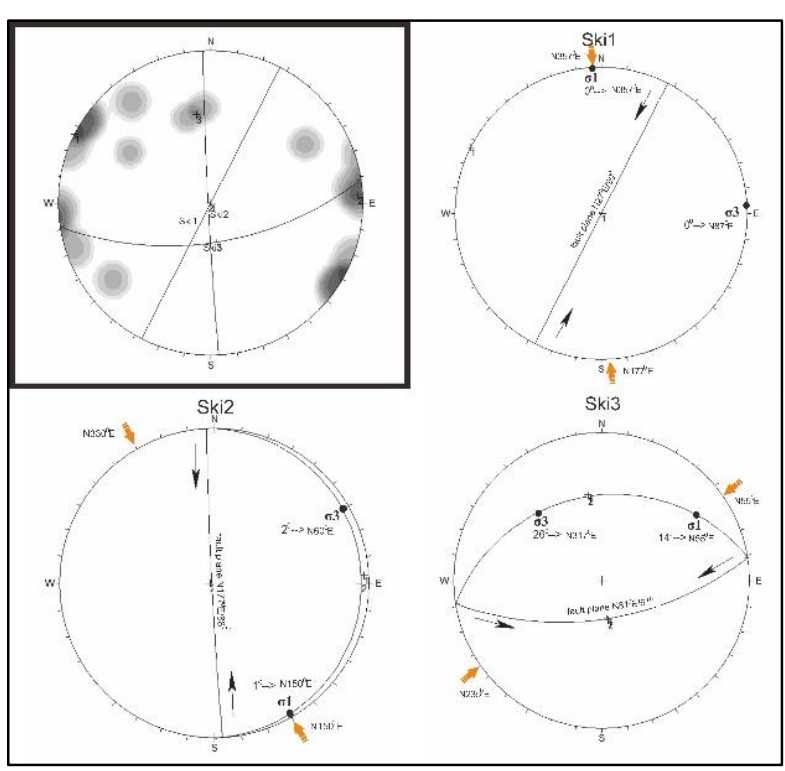

Fig 7. Stress analysis result of sinistral fault

between faults were found. At station 32, ST1 that represented by reverse fault with strike $\mathrm{N} 48^{\circ} \mathrm{E}$ and dip $30^{\circ}$ was cut by reverse fault N $94^{\circ} \mathrm{E} / 48^{\circ}$ from ST 2 . That mean ST1 is older than ST2 because it was cut by ST2. Meanwhile at station 108 , reverse fault $\mathrm{N} 134^{\circ} \mathrm{E} / 68^{\circ}$ that represent ST3 was cutting reverse fault $\mathrm{N} 87^{\circ} \mathrm{E} / 66^{\circ}$ that generated by ST2. In other hand, ST 4 that generated normal fault $\mathrm{N} 90^{\circ} \mathrm{E} / 30^{\circ}$ at station 110 was cutting 2 reverse fault $\mathrm{N} 154^{\circ} \mathrm{E} / 52^{\circ}$ and $\mathrm{N} 160^{\circ} \mathrm{E} / 36^{\circ}$ that result of ST3. Based on cross cutting between fault that found at field, the relative age of main stress was determined where the oldest stress is from northwest-southeast (ST1), following by north-south (ST2) and northeast-southwest (ST3). Whilst stress from east-west is the youngest stress at study area (Table 5).

To determine relative age of all of main stress, cross cutting law was used. At filed, cross cutting

Table 5. History of deformation at study area based on analysis of fault

\begin{tabular}{|c|c|c|c|c|}
\hline $\begin{array}{l}\text { Relative } \\
\text { age }\end{array}$ & $\begin{array}{l}\text { Main } \\
\text { Stress }\end{array}$ & $\begin{array}{c}\text { Compressional Stress } \\
\left(\begin{array}{l}\sigma \\
1\end{array}\right)\end{array}$ & $\begin{array}{c}\text { Extensional stress } \\
\left(\begin{array}{l}\sigma \\
0\end{array}\right)\end{array}$ & Structures formed \\
\hline$\underbrace{\text { Oldest }}_{\text {Youngest }}$ & $\begin{array}{l}\text { ST } 1 \\
\text { ST } 2 \\
\text { ST } 3 \\
\text { ST } 4\end{array}$ & $\begin{array}{l}\text { Southeast-northwest } \\
\text { North-south } \\
\text { Northeast-southwest } \\
\text { East-west }\end{array}$ & $\begin{array}{l}\text { Northeast-southwest } \\
\text { East-west } \\
\text { Southeast-northwest } \\
\text { North-south }\end{array}$ & $\begin{array}{c}\text { Ss2, Ska4, Ska5, Ski2, Sn4, SnG1 and SnG2 } \\
\text { Ss3, Ska2, Ska3, Ski1 and Sn3. } \\
\text { Ss4, SsG, Ska1, Ski3 and Sn2 } \\
\text { Ss1 and Sn1 }\end{array}$ \\
\hline
\end{tabular}

\section{Conclusion}

4 type of fault which are reverse fault, normal fault, dextral fault and sinistral fault were identified by indication of slickenside, fault breccias, displacement and presence of mylonite. Analysis of fault indicate that there are 4 main stresses were controlled the deformation at study area. The relative age of main stress was determined by cross cutting evidence between faults that found during observation at field. The oldest main stress is ST1 with the direction from northwest-southeast. The 
second main stress is from north-south (ST2) and following by third main stress from northeastsouthwest (ST3). Meanwhile, the youngest main stress is ST4 with direction from east-west. All the main stresses were represented the history of deformation at study area.

\section{Acknowledgements}

I wish to thank Dr. Zaiton Harun as my supervisor for his guidance and all constructive comments during this study. I would like to thank Mrs. Nazirah Rahman who help me to collect data at field and give me some ideas for this paper. Lastly, thank you very much to all lecturers from geology program, Universiti Kebangsaan Malaysia.

\section{References}

[1] Gobbett, D. J. 1973. Upper Paleozoic. in. Gobbett, D. J. \& Hutchison, C. S. (Edt). Geology of the Malay Peninsular: 61-95. New York: John Wiley \& Sons, Inc.

[2] Jones, C.R. 1981. The geology and mineral resources of Perlis, north Kedah, and Langkawi Island. Geological Survey Malaysia District Memoir 17: 67-84.

[3] Zaiton Haron \& Basir Jasin. 1999. Implication of the Bok Bak Fault movements on the structure and lithostratigraphy of the Pokok Sena area. Proceeding GEOSEA 98', Ninth Regional Congress on Geology, Mineral and Energy Resource of Southeast Asia: 145153.

[4] Zaiton Harun \& Basir Jasin. 1999. Sempadan litostratigrafi batuan Paleozoik zon baratlaut
Semenanjung Malaysia. Dynamic Stratigraphy \& Tectonics Of Peninsular Malaysia- Seminar II, The Western Belt \& Paleozoic of Peninsular Malaysia: 101104

[5] Abdul Hadi, A. R. 1999. The Lower Permian 'Passage Beds' of the Kubang Pasu Formation,Perlis: Facies, stratification and significance. Dynamic Stratigraphy and Tectonic of Peninsular Malaysia- Seminar II: The Western Belt and Paleozoic of Peninsular Malaysia: 87-100.

[6] Abdul Hadi, A. R. 1999. The upper paleozoic SingaKubang Pasu mega-sequence: some thoughts on basin initiation, depositional and tectonic hostory. Dynamic Stratigraphy and Tectonic of Peninsular MalaysiaSeminar II: The Western Belt and Paleozoic of Peninsular Malaysia: 58-68

[7] Basir Jasin, Zaiton Harun \& Siti Norhajar Hasan. 2003. Black siliceous deposits in Peninsular Malaysia: their occurance and significance. Annual Geological Conference 2003 46: 149-154

[8] Foo, K. Y. 1983. The Paleozoic rocks of Peninsular Malaysia-Stratigraphy and correlation. Proceeding of the Workshopon Stratigraphy Correlation of Thailand and Malaysia 1: 1-19.

[9] Hassan, M. H. \& Lee, C. P. 2002. Stratigraphy of the Jentik Formation, the transitional sequence from the Setul Limestone to the Kubang Pasu Formation at Guar Sanai, Kampung Guar Jentik, Beseri, Perlis - a preliminary study. Geological Society of Malaysia Annual Geological Conference 2002: 169-178.

[10]Kobayashi, T. \& Hamada, T. 1973. Cyrtosymbolids (Trilobita) from the Langgon Red Beds in Northwest Malaya, Malaysia. Geology \& Palaeontology of Southeast Asia 12: 1-28. 